\title{
IMPROVISATION AS A STRATEGY FOR INVENTING DYNAMIC SOLO PLAYS: A STUDY OF TUNJI SOTIMIRIN'S MOLUE
}

\section{Greg Mbajiorgu}

\begin{abstract}
Tunji Sotimirin's pioneering work, Molue, set the pace for the development of one-actor theatre in Nigeria. Ever since, this theatrical genre has grown, attracting various shades of attention, but also encountering its own kind of problems. Through the use of observational design, this study focuses on the story, form, structure, language, character and characterization techniques employed in the making of Sotimirin's improvised solo play Molue. The study unveils how this laboratory oriented artist conceptualises and actualises his one-actor oriented comic production.
\end{abstract}

\section{Introduction}

Theatre in Nigeria has witnessed the development and growth of solo performances. The radicalism and sheer unorthodoxy of this seemingly new approach to theatre practice are as interesting as its attendant economic and artistic potentials. Within the last two decades a number of Nigerian theatre artists have been striving to popularize the actor-based-improvised form of theatre.

Sotimirin's Molue and Funsho Alabi's Escape From Drugs are typical examples of this burgeoning avant-garde theatrical form. Instead of depending primarily on the playwrights' lexical repertoire as the basis for full-blown dramatic production, Tunji Sotimirin and few other Nigerian actors have resorted to a rather impromptu technique of theatre as a strategy for inventing dynamic solo performances with interesting characters.

However, it is important to note, that while Tunji Sotimirin remains the first Nigerian to create his own one-actor piece, Wale Ogunyemi, a renowned Nigerian playwright, actor and director is (historically speaking), the first Nigerian actor to perform a solo drama on the modern stage. Ogunyemi made his historic appearance in a one-actor mime play called, Acts without Words, on the nights of $24^{\text {th }}$ and $25^{\text {th }}$ November, 1966, at the School of Drama, University of Ibadan. Acts Without Words as read from Okotie's production bill 
"is an absurd theatre of gestures that show the bewilderment of man in an irrational world" (Okotie:1966).

The researcher's curiosity to find out why Ogunyemi chose to perform this play at the time he did yielded the following response:

I did not choose to do Acts Without Words, I was asked to do it by Betty Okotie.....realizing this play was not an easy task for me and my director, but I was happy to be able to convey the meaning of my acts to the audience. Again, one being alone on stage with so many people back-stage facilitated my performance that relied squarely on music and movements.

(Ogunyemi, Oral Interview, 2001)

Although, Okotie and Ogunyemi are both celebrated as the first Nigerians to embark on a solo theatrical presentation, it is Tunji Sotimirin - in terms of originality of material - that eventually created the first notable one-man-based theatrical art in Nigeria.

Years after Okotie and Ogunyemi's production of Beckett's mime play, Sotimirin staged his one-man theatrical presentation, Molue in 1987. The significance of this production rests on the fact that it was solely created, directed and performed by Sotimirin.

Osewele (1995:5) rightly identified Sotimirin as “...one sole comedian who can hold his own in the entertainment industry in Nigeria". Sotimirin is also credited for a successful production of another solo play - Gboromiro (1990). In the introductory note to Gboromiro, Reuben Abati (1990) described the performance as:

A mixture of the dramatic, the rhetorical and the poetic....in this performance, Sotimirin borrowed the aesthetics and the spirit of the school's debate format to make a case for the relevance of the theatre and the artists to the growth of the individual in the society.

Although Sotimirin has several other solo productions to his credit, his success as a solo performer rests on his first experiment, Molue. In 1988, barely one year after Sotimirin was celebrated as the first actor to create and produce a one-man-drama, Funsho Alabi, on the sponsorship of U.S.I.S, embarked on a tour of Nigerian Universities with his own solo play Martin Luther King 
Remembered - a dramatization of selected speeches of the legendry black American civil rights activist, which Martin Aginam (1989:20) rightly described as "a montage of loosely connected speeches, structured around the theme of struggle for equality and social justice, but lacking in dramatic conflict". Alabi's production of Martin Luther King remembered was followed by Escape from Drugs a more original solo play he improvised and produced in August, 1989. subsequently, there were solo dramatic experiments and performances by Hafiz Oyetoro, Bayo Alawiye and Tunde Awosanmi. In April, 2001 for example, the University of Ibandan Arts Theatre witnessed a fresh adaptation of The Prime Minister's son recreated and directed by Dele Ogunsola and performed by Bayo Alawiye with Rosline Okoye and Funke Olowu as background choral figures. According to Sanayon Olaoluwa 2001, :

The troika of Ogusola the creative director, Alawiye the actor Okoye and Olowu the back-ground singers deserves special commendation for inaugurating another dimension in the "self apprehension project of theatre".

With that survey of the key solo performers in Nigeria, it is important at this point to present a brief professional background of Tunji Sotimirin, the solo performer whose work is the main interest and focus of this study.

\section{A Brief Professional Background of Tunji Sotimirin}

Tunji Sotimirin's acting career traces back to 1980 when he was recruited as a trainee actor by the University of Lagos centre for cultural studies. In 1984, he obtained a diploma from the Theatre Art Department, University of Ibadan, and was reabsorbed at the centre for cultural studies University of Lagos as Arts Assistant in 1985. On study leave, he went back to University of Ibadan and bagged both his first degree and master's degree in theatre arts. Sotimirin has played prominent roles in numerous stage, film and television productions. He was one of the several Nigerian actors that starred in Wole Soyinka's premire production of King Baabu in August 2005. Tunji Sotimirin is rightly acknowledged as the first Nigerian to create, direct and perform a one-man theatrical presentation on the 
contemporary Nigerian stage. His successful self-based solo experiments are Molue (1987) and Gboromiro (1989) Sotimirin's hilarious performances are essentially designed to entertain and amuse his populist audience.

\section{Sotimirin's Molue}

According to Ezeani and Ewuziem (1989) Molue is a series of comic sketches that highlights the everyday happenings in the ram shackled Lagos city buses". Beyond merely throwing light on the daily occurrences, the researcher sees the Molue series of sketches as theatrical interpretations of road side characters frequently found in our commercial buses. In one of the sketches, the bus conductor, Sotimirin attempts to produce the typical words, behaviour and gestures of an interesting Lagos commercial bus conductor. The respective archetypal characters that informed the other sketches are, the bus driver, the itinerant drug hawker, the traditional herbalist and the itinerant beggar. All these are phenomenal characters found in the Lagos city commercial buses. Molue sketches are inspired by the actions and reactions of true-life characters. An illustrative outline of one of the five sketches that make up the Molue series is as follows:

\section{The Bus Conductor}

$\mathbf{1}^{\text {st }}$ Bit: $\quad$ Bus conductor is seen screaming the different bus $\mathbf{2}^{\text {nd }}$ Bit: $\quad$ An imaginary road transport worker stops the bus. There in an encounter between the driver and the road transport worker. Fight ensues... driver and bus conductor with support of passengers triumph at last, etc.

$\mathbf{3}^{\text {rd }}$ Bit: $\quad$ Bus conductor, in a more aggressive and authoritative Mood, is seen, shouting and quarrelling with passengers over tickets and change etc.

$4^{\text {th }}$ Bit: $\quad$ (the bus is filled to the brim) Bus conductor makes a signal to bus driver to move and resumes his 
hilarious songs. As he sings, he moves from seat to seat, collecting money from passengers, issuing tickets and announcing the different bus routes and bus stops, etc.

The notations above are illustrative of the fragile improvisational out-line or scenario that inspire the actions, dialogues and words in Sotimirin's series of comic sketches. Sotimirin's sketchy scenario or jotting contains nothing but the necessary reference points that are meant to guide and inspire him through the rigorous process of theatrical construction that goes beyond the verbal domain. The outline above, does not even give us a thorough clue of what the characters say or do. As we can see from the diagrams above; what Sotimirin presents as his performance plan on paper contains no hint of the actual statements and actions of The Bus Conductor, The Bus Driver or The Road Transport Worker. According to Sotimirin (2001):

It is only my rehearsal guidelines that I put down on paper So as not to mix up the different stages in the development of the improvisation. I only look at the guideline to remember which character or which situation or action to focus on or what movement that should guide my improvisation on stage. Like the traditional folklorist, I do not work with a fixed text or a written script. Molue was conceived as I pondered on the regular hilarious Behaviour of the every day characters in the Molue buses. As I consciously observe these characters, I started to visualize each character's actions and statements as distinct theatrical sketches and performances... if I encounter difficulty while rehearsing at home, I go back to the bus the next day and re-observe the behaviour of these phenomenal characters again. I spend a lot of time observing how each character exhibits his peculiar traits and mannerisms.

Sotimirin's jottings or guidelines which enable him to recall the details of events and actions in the buses can be seen as the 
visible structural foundation of his highly humorous performances. Though his self-based variety of solo episodes are steeped in the superficiality of day to day occurrences, he still excites and electrifies his audience each time he goes on stage. As observed by Andy Ike Ezeani and Alvan Ewuzie (1989:20):

Molue was one of those stage presentations that the Audience enjoyed.. The Unilag Arts Theatre jampacked, only had a few slow moments while the performance lasted. These were either when the actor retired to change costume or when towards the end of the performance there were signs that he had drained too much humour for one evening.

Unlike other Nigerian Solo Performers such as Funsho Alabi, Tunde Awosanmi, Hafiz Oyetoro, etc. who imagine and create their plot outlines, Tunji Sotimirin creates his plot outline by direct observation of true life situations. In other words, his plot outline is not the product of his imagination but the product of his careful observation. Like Traditional African Griots, Sotimirin has no need to master a fixed oral text. As earlier pointed out, he simply studies his sketchy outlines, based on which he improvises the details of his stories and actions during each performance. His oral text which is not fixed gives him room for re-adjustment and improvement. David Buchan (1990), has this to say about the traditional oral text composition technique which this solo performer is currently exploring:

One of the major literary findings of this century was the discovery that although we habitually equate composition with writing, another method of composition has also existed: oral composition employed by non-literate people for literary creation. It presumably antedated and certainly paralleled the method of written composition. Milman Parry and Albert Lord (1960) of Harvard, demonstrated through their field research with Living oral epic tradition in Yugoslavia how people who Could not read and write were able to create and perform poems of length and complexity, and their findings have, for many, 
literature implications that are still being investigated. It appears probably, however, that the Odyssey and parts of the Bible were orally composed. The Nonliterate composer-performer learns not a fixed text but a story outline and a technique for re-creation of the story in performance. The technique involves the deployment of formulaic language and formulaic narrative element within basic structural patterns.

Despite the high literacy level of Sotimirin, he still prefers to explore this oral compositional technique, not only because it is a convenient method for his "self based" theatre, but also because he is truly interested in reviving and perpetuating this technique associated with Traditional African Griots and Story Tellers.

\section{Form and Structure in Sotimirin's Molue}

Sotimirin's sketches are segmented and episodic, each sketch is a study of the statements and mannerisms of a single character with minimal characterization. These characters that are studied separately in the different sketches are roadside, undignified characters whose actions and utterances provide a pertinent interpretation to reality. According to Funsho Alabi, (2001):

The beauty of Sotimirin's performance lies in his ability to recreate the everyday phrases of these funny and subversive elements in a way that baffle his audience. Through direct dramatic imitation, he reproduces in words and gestures the funny statements and actions of bus conductors, bus drivers, drug hawkers, itinerant beggars and other such characters in the Lagos city commercial buses popularly known as Molue.

Despite the apparent strength and attractive features of Sotimirin's One-man Oriented Comic Presentations, the probability of his monologue - prone acts being boring is very high, but as mentioned earlier, his presentations are usually lively and highly entertaining. 
The success of his solo performance lies not only in his meticulous representation of daily occurrences but also in his ability to explore the comic in real life. For these reasons, Sotimirin's theatre provides great amusement for his audience.

The five sketches that make up his performances have no direct structural links at all. The only things that unite the sketches are the setting, the moving bus and the fact that Sotimirin is the solo actor that performs all the sketches.

Sotimirin also establishes imaginary dramatic environments and imaginary stage properties through highly expressive mime techniques, gestures, movements and verbal utterances. Nothing is provided for these sketches except costume. All the other stage items are established through the use of body and voice. This variety of sketches contains no implied dramatic conflict and does not require the single-actor dialogue techniques explored in Funsho Alabi's Escape from Drugs. He creates his sketches directly out of the statements, behaviour or the actions of these true life characters. His Molue sketches belong to the category of presentations that Patrice Pavis classified as Theatre of Everyday Life. This kind of theatre, according to Pavis (1996:391); "Aims to discover and display every day life, which has always been considered too insignificant and specific to be shown on stage". Pavis refers to such true life sketches as "... an assemblage of fragments of every day reality, tatters of language showing the banal every day life of the disadvantaged class" (1996:391).

One also observes that despite the humorous nature of Sotimirin's characters, his sketches are mostly static because they simply display unconnected statements and portraits that can be humorously realized even without detailed movement of the actor's body. His Molue sketches would have strongly appealed to us as comedy of character if he had carefully explored the psychological and "moral" attributes of these every day figures.

\section{Language, Character and Characterization Techniques in Molue}

Like most solo plays, Sotimirin's Molue is rooted in language. In a recent interview, Louis Catron draws our attention to the language based nature of all solo plays. According to Catron (2005); "A friend who is a solo playwright - actor says she believes 
monodramas depend more on language - they are dramas of language - than do multi-character plays".

The language of the characters in Molue is the language of the impoverished and oppressed, the language of hopeless, undignified Road-side-touts and clowns. Their use of Vernacular, Pidgin English and Wrong Grammatical Expressions helps a lot in depicting their banal state of being.

Sotimirin's characters are complete illiterates who combine words with visual comic postures and movements to make humorous statements. These non-intellectual characters, utter verbal abuses and say things that sound odd, ludicrous and amusing at the same time.

Again, Sotimirin's ability to create mechanical sound and other forms of sounds through his voice, adds to the beauty of his comic sketches. He employs humour as his main tool for establishing his characters, and all his sketches satirize the funny but disgusting happenings in our city commercial buses. According to Sotimirin (2001), "I see Molue as a mini Nigeria, the characters in Molue reflect the chaotic state of the Nigerian Nation". This chaotic state is vividly captured in Sotimirin's humorous interpretations that are steeped in comic words and actions

Like most solo actors, Tunji Sotimirin uses his vocal instrument to evoke the psychological and physical nature of his characters. Through conscious exploration of his vocal apparatus, Sotimirin has learnt to formulate the different tones and vocal rhythms for different roles. He utilizes a great deal of his rehearsal time to practice and master how to get into the physical, psychological and vocal characteristics of his different roles, how best to manipulate imaginary objects and make them perceptible and visible in the minds of his audience.

The noticeable lack of character transformation and depth in Molue sketches results from the fact that Sotimirin's style of dramaturgy is rooted in specific character traits and peculiar mannerisms. Such specific character studies that abound in Sotimirin's sketches are clear examples of those that Louis Catron (2000) describes as showing "selected basic essential of the subject but not all details". The characters in Molue are woven around tiny 
plots and the beauty of Molue sketches emerge not from their brief plots but from specific fascinating mannerisms, words and actions of the phenomenal true-life characters that are portrayed.

From this study, we can see that improvisation, language, gestures, postures and other forms of body expressions and movements are among the Solo Performers strategies for inventing dynamic characterization.

Some of the important dramatic and literary devices that Sotimirin appropriates in his solo performance projects are discussed below:

\section{Use of Expressionistic Device}

The banal statements and lamentations of the Bus Conductor, the Bus Driver, the Itinerant herbalist and other such characters in Molue are expressions that in one way or the other $\mathrm{x}-$ ray the Solo Performer's state of mind, his attitude to the social problems that hinder his progress. In other words, Sotimirin's presentations, to some extent, reveal his psychic make-up.

\section{Use of Autobiographical Techniques}

According to Mel Shapiro (1997-2), "autobiography starts when the actor begins exploiting feelings, memories, dreams and fantasies that he or she has experienced" Although Tunji Sotimirin is not telling his true life story in Molue, his performance can be referred to as an autobiography in the sense that he is enacting and presenting the story or lives of other people whose experiences in one way or the other affect his existence.

\section{The Wanderer Motif in Molue}

In Sotimirin's production of Molue, we find some characters that can be described as roving characters. For example the conductor in Sotimirin's Molue hovers from one end of the bus to the other, collecting each imaginary passenger's bus fare and ushering in more "passengers" Other wanderers in Sotimirin's imaginary bus are: The Itinerant Fulani Beggar and Hawker. These wanderers are no repository of significant events in their communities. Their acts do not project ideas that border on cultural pride, e.g., Sotimirin's typical characters like The Drug Hawker, The 
Traditional Herb seller, the Fulani Beggar, etc. are characters that wander from place to place, characters whose sole means of survival is generated from endless wandering.

\section{Poverty of Theatrical Logistics}

Sotimirin produced his Molue sketches in line with Jerzy Grotowski's minimalist performing style that is known for its extreme economy of such production resources as cast, set, props, costume, etc. In fact, the success of his Solo Performance rests squarely on his ability to mimic the different archetypal characters that are normally seen in our commercial buses.

\section{Conclusion}

So far, we have examined how this laboratory oriented artist of the theatre conceptualized and actualized his solo play (Molue). The one interesting thing which has been observed from this study and previous studies in this area is that solo production in Nigeria has developed more as performing arts. Contrary to the Nigeria experience, the practice of contemporary monodrama in Europe and America has grown both as a collaborative art and as a literary art. In Nigeria, as I mentioned earlier, the solo theatrical experiment has been championed by actors alone and almost all Nigerian solo plays are improvised. So far, apart from the pioneering, contribution of the late Wale Ogunyemi (Playwright/Actor) and the living Betty Okotie (Director), no other notable Nigerian director and playwright has contributed to the growth and development of this sub-theatrical genre.

Finally, it is important to mention that experiments in solo productions have created many problems and prospects for theatre scholars, artists, historians and critics in Nigeria. In this era of home video productions and multi-channel television services, it can no longer be disputed that experiments and studies in minimalist approaches to theatre production are among the many challenges that theatre scholars and practitioners must have to face in order to capture the $21^{\text {st }}$ century entertainment market. 


\section{References.}

Abati, R. Foreword to Sotimirin's production bill for Gboromiro. Ibdadan, 1990.

Alabi, F. Oral Interview, Lagos, May 24, 2001.

Buchan, D. "Folk Literature" Encyclopedia of Literature and Criticism. Martin Coyle, Peter Garside, Malcom Kelsal and John Reck edited, London: Routledge, 1990.

Catron, L.E. "Jenna Glatzers Interview with L.E Catron" 14 May, 2005. www.absolutewrite,com.screenwriting/louisctron.htm.

Catron, L.E The Power of One - The Solo Play for Playwrights, Actors and Directors, Portsmouth: Heinemann. 2000.

Ezeani, A. and Ewuzie, A. "One man many Antics" Daily Champion. Saturday, April 22, 1989, 20.

Oditta, I. "Conflicting Image of The Prime Minister's Son" "Comet" Saturday, July, 7, 2001,20.

Ogunyemi, W. Oral Interview, Ibadan, July 20, 2001.

Okotie, B. Director's Note for Acts without words. (Production bill) Ibadan 1966.

Olaoluwa, S. "From King Baabu to The Prime Minister's Son" Post Express. Sunday, August 26, $2001,21$.

Osewele, N. "It's Not Easy To Make People Laugh" National Concord.

Thursday, March 22, 1990.

Pavis, P. Dictionary of Theatre: Terms, Concepts and Analysis, Toronto: University of Toronto press Inc. 1996.

Shapiro, M. An Actor Performs New York: Harcourt Brace College Publishers, 1997.

Sotimirin, T. Oral Interview, Lagos, May 13, 2001. 